\title{
Scientific Method and the Law
}

F LAW is a science, it is, like economics, ethics, politics, a social science, 1 provided that any social science is really a science and provided further that there is such a thing as science at all. This, I should say, is a sufficiently cautious way of expressing the fact that for many centuries there has been something called "theoretical jurisprudence" in which men have striven to state the facts of law, if there are such facts, in a form as generalized as that which would be used for asserting that all men are mortal, if they are mortal. There was a time when theoretical jurisprudence was more important than theoretical physics or mechanics and a vast deal more was written about the first than either the second or the third. But since the seventeenth century that has not been the case. About that time mechanics and physics and the like made a hesitant entry into theoretical study as branches of Natural Philosophy, itself a humble associate of Moral Philosophy, which was real Philosophy, but they waxed so fat and proud that in the nineteenth century they repudiated the association altogether and became Science in terrific majuscules, leaving Philosophy to vaporing metaphysicians and Ethics, Politics and Jurisprudence literally nowhere. The defection was not noticed to any great extent in England and America where procedural changes occupied the minds and activities of lawyers, but on the European Continent, it threw Jurisprudence into the arms of Metaphysics from which unhappy liaison only the convulsions of a transforming social structure have partially liberated her.

It is necessary to say all this by way of preparing us for a consideration of the frequent attempts made in the last generation to arrange a more permanent and more legitimate union between jurisprudence and Science, Science still arrogantly capitalized, the science of physical and mechanical inplications, of which the distinguishing mark is the laboratory or plant and which is inordinately proud of being able to use mathematical symbols for the statement of its results. The proposed union has many advantages and I slould be the last to forbid the banns but if expectations of undisturbed felicity are keyed too high, I foresee certain complications.

The particular attempt to associate law and science that has occasioned the foregoing statenents is that whicl is evidenced by a recent little book published by the Johns Hopkins University Institute for the Study of Law. It is entitled From the Physical to the Soctal Scrences, by M. Jacques Rueff, a graduate of the École Polytechnique, and, I am sure, a highly competent and scientifically trained engineer. 
Mr. Herman Green has translated it and Professor Oliphant and Mr. Abram Hewitt add a long and most instructive preface. M. Rueff's subtitle declares the book to be an introduction to "a Study of Economic and Ethical Theory" and the preface makes the necessary application of the writer's ideas to the law. ${ }^{1}$

It is obvious that a book for which the École Polytechnique and the Johns Hopkins Law Institute can be vouched to warranty has merits. Its obvious merits are freshness and vigor of expression of idea, and a certain boldness in engaging profound questions which is both stimulating and helpful. It happens often enough that those who rediscover for themselves a much debated problem, find aspects and facts that have escaped the notice of generations of controversialists. All that M. Rueff says is worth attending to, although most of it may not be quite so convincing and illuminating as his sponsors and perhaps he himself suppose. ${ }^{2}$

It was once said of a certain book that there were many new and admirable things in it but that the new things were not admirable and the admirable things were not new. Certainly this judgment cannot be made of the whole of M. Rueff's book, but it describes part of it not unfairly. For it is surprising to find him declaring that he had "demonstrated" 3 the fact that economics can be stated mathematically. Have we really waited so long for that demonstration? Stanley Jevons thought he had made it in 1862 with his Generar Mathematical Theory of Political Economy and more completely in his

IM. Georges Renard of Nancy, whose admirable lectures on legal philosophy present vividly and charmingly the point of view of Christian idealism, has discussed $M$. Rueff and $M$. Duguit in a brief article with the name title as that of M. Rueff, Des Sctences Phystoues aux Science Morales (1929). The article has been separately publisbed and offers a criticism of Rueff from a point of view very different froin that to be found in the following pages.

2 I should like to compress into a foot-note my pent-up irritation at the misuse of the names of Plato and Aristotle. Aristotle did not say that most men were born slaves (p. $\mathrm{xx}$ ), but that some men were. Nor did either Plato or Aristotle say what $M$. Rueff ascribes to them on p. 81. So far from asserting that there is nothing sound in slaves (ibid.), Plato in the relevant passage (evidently, LAws, $776 \mathrm{E}-777 \mathrm{~B}$ ) makes the Athenian interlocutor quote this view as one of two possible ways of regarding slaves and the one of which he imphedly disapproves. As for the Aristotelian citation which apparently comes froin the PoLITICs (I, 5, 1254b), it is not there stated that Nature makes the bodies of slaves different from those of freemen but that, while it would be a good thing if that were the case, as a matter of fact, it is not so. That Plato and Aristotle retain their authority in the age of the Saturday Evening Post is shightly surprising but apparently they do, and they should therefore not be charged with what they did not say. M. Rueff quotes thein, as so many others do, to prove that, what good men now almost unanimously reject, great men in ancient times found fully acceptable. It is therefore of some importance to be sure about our great men's views.

3 Ruefe, From the Phystcat to the Soctai Sctences (1929) 145. 
famous text-book published in 1871. Marshall, who may be taken as the type of the older economists, and Mr. Keynes, who is surely a modern one, have freely used curves and differentials and exponents and equations in setting forth their doctrines. We need not therefore have been so fully and explicitly assured that the thing could be done, and speaking for myself, I should suggest that it was better done by Jevons than $M$. Rueff manages it.

I fear that what M. Rueff says of the "Law of Identity" and the "Law of Casuabty," which are so conveniently inherent in the human mind, belongs to the category of new and admirable things as above defined. In the case of a man wlio, like $M$. Rueff, will not trouble himself about metaphysics, it is distressing to see so many arbitrary metaplyysical assumptions treated as established. Are we all Eleatics? Is error wholly dependent on ambiguity of language? It is not certain, although M. Rueff apparently thinks so. And that the statement of a fact createst the fact, as he repeatedly asserts, is a crude Nominalism which in that form would have seemed to William of Occam six centuries ago and today can hardly claim to be treated seriously. The point seems to be that the problems relating to truth, to thinking and to value are many and serious, and it is not clear that $M$. Rueff has thoroughly canvassed any considerable number of them. When he speaks of the notion of "ought" for instance, he makes the statement that "The man who fears highwaymen discovers the right to life." That is a rather naïve formalism since it neglects the fact that when instinct is accompamed by consciousness the sense of "ought" is already present in a certain form and this form can be made the basis of a valuation. Primitive people often have a rigid sense of the obligatory character of certain rules although they know of no instance of a violation of them and indeed can scarcely conceive of such a violation. That is shown by the fact that in so many primitive regulations there is no sanction nor does it occur to anyone that a sanction is necessary.

If $M$. Rueff does not seem to be the safest of guides in those matters which are at the foundation of legal and social theory, he may plead that the principal purpose of his book is a different thing. He wishes to apply a single method to the facts isolated by physics, by ethics and by economics, and to treat their "laws" as of precisely the same kind. Mr. Cardozo has warned us in one of his books that this renewed identification of the "laws of nature" with law in the restricted sense was a possibility of modern study and this attempt of $\mathrm{M}$. Rueff so to identify them is valuable and important whether we do or do not agree with his conclusions.

4 Ibid. 78. 
His contention may be said to be the following. A physical law is the statement that a certain sequence exists in phenomena. But this is merely a generalization of observations which have noted that sequence. Now moral and social laws are similarly generalizations of facts observed or observable. The capital difference so often declared to exist between these two kinds of laws is based on the hypothesis that the former are invariable and certain and the latter fluctuating and subject to human arbitrary whims.

This difference M. Rueff rejects. Undoubtedly slavery was legal formerly and is not legal now. The law, however, has not therefore fluctuated. The circumstances which created legal slavery have disappeared but the legality of slavery was as much the product of the totality of human and economic conditions then existing as its present illegality is the product of present conditions of this sort. Similarly, a physical law is equally the product of conditions. The law that pure water vaporizes at $100^{\circ}$ Centrigrade is "true" only at sea-level and under normal atmospheric pressure and in the absence of other disturbing conditions. If these conditions cannot be postulated, we cannot say that water will boil; precisely as we may say that, if the Mediterranean nations in $400 \mathrm{~B}$. C. had been differently constituted and had lived under different conditions, they might not have had slaves.

So far, so good. We may fully assent to all this. But if $M$. Rueff had analyzed his facts as thoroughly as a pupil of Boutroux and Henri Poincaré should have done, lee might have observed his tenses more closely. Your physical law is a generalization of past experiences and every single experience, being an event, is unique, and is unalterable. Similarly your political or moral law which makes Stichus the slave of Aulus may be considered a generalization of the fact that at a certain time such a relationship had long and widely existed. But the fact of such past existence is in neither case the important part of the law as far as men are concerned. M. Rueff very strongly asserts a kind of pragmatic relativism, which, however, shifts into vitalism and intuitionism at awkward crises in his reasoming, but if we take him at his word, all laws, physical as well as moral, are intelligible only in relation to the liuman beings who formulate them. In that case what concerns them is that state of expectancy or anxiety which is the only sure human attitude to the world. Can we predict with fair certainty that pure distilled water at sea-level and under normal pressure will boil at $100^{\circ}$ Centigrade? I think we should noost of us not hesitate to do so. Can we predict that a people like the Romans or Athenians who might live in the future in the same numbers as before in Athens or Rome, and be without knowledge of steam, gas or electricity, will 
own and use slaves? I am afraid we cannot. And that is a large difference.

We may say of course that the difference consists in the fact that the conditions necessary to make water boil are few and simple and that we can learn them readily. We have made the experiment so often that we are safe in believing that we do know them all, although as scientists we will not dare to assert that an exceptional situation may not arise which will compel us to add new conditions. But we do not know all the conditions which made slavery a part of the social structure, so that we could not be at all sure that at any given moment all those conditions are present. We are sure that there were many conditions, very many indeed, and complex ones.

The difference, therefore, it may be urged, is purely a quantitative one. The boiling of water and the use of slaves both depend on certain conditions. We know practically all the conditions necessary for the former. We know only some of the conditions necessary for the latter. Unfortunately, that would leave us in the situation of saying that there is no political or moral law which we do know, since in no case do we know anything like all the conditions that have created the situation in which the law was in past time operative, whether it operated only once or a million times. We cannot save the identification of political and natural laws except at the cost of confessing what may be called illiteracy, as to the former.

Now, this is a reductio ad absurdum, since we can, as a matter of fact, make a prediction as to certain social laws almost as confidently never quite as confidently - as we can about some physical ones. We can say that in no country of Europe or America now existimg or likely to exist within the range of reasonable conjecture, will any and every deliberate homicide of one adult liuman being by another be legally permissible. We say this almost as surely as we say that water under the previously mentioned conditions will boil, and in either case we can adjust our conduct safely enough to this prediction. But we really know only a small number of the conditions that have made luman life so important while we know practically all the conditions that make water boil. Evidently it is not necessary to know as much in the one case, as in the other in order to make a safe prediction. All we need know is the fact that in every one of these countries there is a written provision, called a statute, forbidding murder, and further the fact that all these countries are inhabited by people who closely resemble us and finally that we ourselves have been taught to regard murder with horror. From these facts, few as they are, we predict that in every one of these countries the statutory provision against murder will in 
some way be sought to be enforced, even if not successfully, and we shall almost surely be proved right upon investigation.

Even these three facts we need not really know, and any one of them is a complicated fact of which we have certainly not investigated all the elements. Our prophecy depends on certain intuitional leaps that we have made, not, as in the case of boiling water, on certain generalized observations. Still $M$. Rueff cannot be denied the triumph of showing that relatively to men, the prediction that one law will work under certain conditions is no surer than that the other will.

But our physical and our social or political predictions - shall we call them "juristic?" - are contrasted in still another way. That water will boil under certain conditions is so nearly certain that we ignore the fact that it is not quite certain. And most of our physical laws are of this sort. Indeed - and this is essential - we never think of stating them as laws till they have been shown to possess this enormously high degree of predictability. But there are very few juristic laws of which the operation is as predictable as in the case of the prohibition against murder. Many of these laws allow no predictions at all, since a guess is not a prediction and in some of them the operation is predictable only with a large margin of doubt. In other words, whereas the range of uncertainty in the case of physical laws is a minute variation between the most nearly certain and the least certain, in the case of juristic laws the range is from a slight balance of probability in favor of effectuation to a very high degree of probability.

Let us take a specific example. At the moment of writing there is a controversy in Ohio which has been much discussed in the press. Is it a contempt of court to speak abusively of a judge in relation to a case he has already decided? In England, it has been several times decided that it was a contempt. The courts of some American states have reached a similar conclusion. Knowing the tendency of English and American judges to follow previous decisions, we may say that in all probability in England and those states, the courts would decide again that such newspaper abuse was a contempt. In other states an opposite result has been reached. In those states the probability is therefore against this abuse being considered a contempt. But what about Ohio, where no such previous decision has been rendered? What will the court say there?

If we had a large experience of the Judges of the higher court or courts, if we knew their education and habits, if we knew how far they read the newspapers, how prone they are to be influenced or antagonized by discussions in the press, low they estimate the jurisdictions where similar cases have been decided, how likely or unlikely they are 
to be swayed by symbolic words like "free speecli," how their imagination functions, we might hazard a prediction as to how these judges will determine this question. It will not be a certain prediction, because there are many more possible factors than those I lave listed, but it will be better than a guess. But it is obvious that the vast majority of us can know very hittle even of the things just mentioned and can therefore only guess at what the court will do - a guess that is based on what we would do ourselves. And yet what the judges will say, will certainly determine in the case of the Ohio editors, whether what they did was a contempt or not. ${ }^{5}$

And in point of fact, the vast majority of matters which form the subject of legal study are much more like this contempt case than they are like the prohibition of murder. That is to say, the predictability of the law on any specific point is slight. It must almost inevitably be so because the mere fact that courts are asked to pass upon a question shows ordinarily that there is some doubt about it. It is perfectly true that there are a great many situations in whicls there is little doubt, but obviously the controverted cases will be the doubtful ones, and it is these which engross the attention of lawyers. New law is constantly made by the generalization of lawyers' conclusions about them. Therefore the pliysical law on which we can rely so confidently because we know nearly all the necessary conditions of its operation must be contrasted, not with these juristic laws on which we can rely although we know only a few of the conditions of their operation, but with those juristic laws which we can only hesitantly conjecture, of whose necessary conditions we know very hittle and on whose operation we dare not rely at all.

The point is that the "scientific" method, that is to say, the method at present in use in physics and chemistry, and to a very much more limited extent in biology, is applicable only when the predictability reaches a very high percentage. It is one of the many illustrations of the doctrine that quantitative differences are, properly speaking, qualitative - a doctrine so eminently relativist that $M$. Rueff will surely accept it. ${ }^{6}$ It is quite true that the mathematical theory of probability can be applied to all groups of data, those in whicl the probability is one in a million as well as those in which it is 999,999 in a million. But however mathematical and precise an equation looks, we must

5 The fact that the operation of a present legal rule depends upon the future action of a judge or some judge-like official - this fact, which has been so clearly stated hy Mr. Justice Holmes (1923) 21, Mich. L. Rev. 530, (Cf. Cardozo, The GrowTH OF THE LAW (1924) 44 et seq.) -has, it need hardly be said, nothing to do with the rule of stare decisis and is as true for those jurisdictions which profess to ohserve the rule as it is for those which profess not to.

${ }^{6} C f$. RITTER, Is Life QUANTITy (ScIENCE (1929) LXIX, pp. 425-427). 
remember that when the range of error is very high, the equation tells us nothing except that the range of error is very high. One does not construct bridges if the probability that they will fall is one in two, but systems of law must be constructed on probabilities as hazardous as that or more so. That fact must warn us that, for the present, bridges and legal systems cannot be dealt with quite in the same way.

We shall some day know more, of course. But to say that we shall some day know as much about juristic laws as we do about the conditions which make water boil, is an unproven and unprovable assumption. In any case it is the present or the immediate future which concerns us, and not that remote beatitude of scientific legal certainty which will come at Latter Lammas, and we must ask ourselves whether it can serve any useful purpose to state the law of hability of a newspaper for contempt in Ohio in the same symbolic language as that which we should use for the coefficient of expansion of an iron bar subjected to a gradually rising temperature under a constant pressure.

That it can be so stated is evident enough. I do not see why we cannot write $\mathrm{n}(\mathrm{j} !)=\mathrm{p}$ in which $j$ is the habitual behavior of any one Ohio judge, $n$ the number of such judges, $!$ the product of all the factors from zero to the indefinite number (more than a million) which actually may influence them in this case, and $p$ the probability that his decision will be any particular one. And I do not think it would be impossible to plot the curve of this equation in such a way as to give it a specious resemblance to the equation which expresses the pull of gravity, $\mathrm{w}=\mathrm{G} 4 / 3 \pi \mathrm{R} \Delta \mathrm{m}$. But our first equation would do us no good because while any change in $n$ or $j$ or $/$ might produce a change in $p$ we do not know what sort of a change nor how great a change. Whether stated in words or in letters, it is a perfectly sterile statement from which no inference can be drawn and all successive transformations of it would be an endless tautology. That is not so of $\mathrm{w}=\mathrm{G} 4 / 3 \pi \mathrm{R} \Delta \mathrm{m}$, because any change here would make a precisely calculable change in the rise and fall of the tides, the speed of an aeroplane or the length of the solar year.

That is not to say that the social sciences cannot be advantageously expressed in symbolic terms. ${ }^{7}$ Indeed, any technical terminology is a form of symbolism and English law was once exclusively expressed in what might be called a symbolic, because artificial, language, the later form of "Law-French." But it must be a symbolism derived from its own facts and used for its own purposes. We can only proceed with

7 One might instance the attempt of Poliack, Perspertive und Symbol in Philosophie UND Rechiswissenceraft (Berlin, 1912) 391-420, to write in a graphic symbolism any one of three legal theories. 
M. Rueff from the physical to the social sciences if he will consent to abandon his language for the journey and learn ours.

We can scarcely blame him for declining to do so. We do not speak our own language very well or better our Babel of tongues. If $M$. Rueff's book will induce American lawyers to acquire a precise legal alphabet or a legal algebra or a legal calculus and persist in it, that will be more than sufficient justification for the writing, the translation, and the publication, of the book. Perhaps the editors scarcely promised themselves even so much.

Max Radin.

SCEOOL OF JURISPRUDENCE, UNIVERSTTX OF CATLIFORNIA. 